\title{
Toxic and Essential Metals in Staple Foods Commonly Consumed by Students in Ekiti State, South West, Nigeria.
}

\author{
Ojo Olabimpe Iyabo ${ }^{1}$, Ogundiran Mary B. ${ }^{2} \&$ Adebayo Oluwafemi L. ${ }^{1}$ \\ ${ }^{1}$ Chemistry Department, College of Education, Ikere-Ekiti, Nigeria \\ ${ }^{2}$ Chemistry Department, University of Ibadan, Ibadan, Oyo State, Nigeria \\ Correspondence: Ojo Olabimpe Iyabo, Chemistry Department, College of Education, Ikere-Ekiti, Ekiti State, \\ Nigeria. Tel: 234-806-679-3330. E-mail: bimfaitho@yahoo.com
}

$\begin{array}{lc}\text { Received: January 6, } 2015 & \text { Accepted: January 27, } 2015 \quad \text { Online Published: April 21, } 2015 \\ \text { doi:10.5539/ijc.v7n1p155 } & \text { URL: http://dx.doi.org/10.5539/ijc.v7n1p155 }\end{array}$

\begin{abstract}
Humans are exposed to Toxic Metals(TMs) and Essential Metals (EMs) through different sources but the most important are staple foods. Exposure to TMs and EMs may bring about harmful and beneficial effects respectively. Previous studies on the assessment of TMs and EMs levels in staple foods commonly consumed in Nigeria were focused on general populace while less attention had been paid to staple foods consumed by students within University campuses. Hence, this study was designed to determine the concentrations of selected TMs and EMs in staple foods commonly consumed by University students given the peculiar nature of their feeding habit.
\end{abstract}

A structured questionnaire to obtain information on the kinds of staple foods consumed was administered to 200 consenting students of Ekiti State University, Ado Ekiti. Some samples of staple foods were identified. The identified staple foods were purchased from food vendors and local market in the research location and sorted into categories. Staple foods were oven dried at $105^{\circ} \mathrm{C}$ for $24 \mathrm{hrs}$ and pulverized. One gramme each of staple food was digested using dry ashing. The digests were analysed for Zinc, Copper, Lead and Cadmium using atomic absorption spectrophotornetes, Data were subjected to descriptive statistics and compared with permissible limits as set by FAOIWHO guidelines for food standard

Questionnaire indicated the followings: Spaghetti, jollof rice, rice with stew, wheat with soup, white and red beans, akara (beans cake), moin-moin, melon, groundnut, yam, amala, ( cassava and yam flour), garri (fried cassava), eba, potato as staple foods usually consumed by the University students. The staple foods were categorized into cereals, legumes and tubers respectively. In the staple foods, the mean concentration $\backslash(\mathrm{mg} / \mathrm{kg})$ of zinc, copper, Cadmium and Lead ranged respectively as follows: 11.1 $\pm 5.34-16.6 \pm 11.9,3.70 \pm 3.30-5.60 \pm 5.10$, $0.02 \pm 0.02-0.28 \pm 0.23$ and $0.10 \pm 0.10-0.22 \pm 0.17$.respectively.Hightest concentrations $(\mathrm{mg} / \mathrm{kg}$ ) of zinc (16.6 $\pm 11-9)$ and cadmium $(0.28 \pm 0.23)$ were found in cereals while the highest concentration of copper (5.60 \pm 5.10$)$ and lead $(0.22 \pm 0.17)$ were found in legumes and tubers respectively. The concentrations of zinc, copper, and lead were within the permissible limits set by FAO/WHO guildelines for food standard while cadmium concentration in cereals such as rice and wheat were above the permissible limits

Staple Foods consumed by the University students were relatively safe in terms of toxic and essential metals contamination except cereals whose cadmium level exceeded the permissible limit.

Keywords: staple foods, essential and toxic metals, university students.

\section{Introduction}

Foods are important for human survival. They may contain essential metals and toxic metals which can either be beneficial or hazardous to man. (WHO, 2007).

Metals in foods are to pay attention to, because of their essential benefit and toxic effects on human health. The ranges between beneficial and toxic levels are usually small. High concentrations of lead can cause irreversible brain and neurological damage, seizure, coma and death if not treated immediately.

In adults, lead is very detrimental to the cardiovascular system, Exposure to it regularly may cause high blood pressure and are at increased risk for myocardial infarction and stroke. ATSDR (2011). Consumption of 
cadmium even at lower levels over a long period of time can lead to a build up cadmium in the kidney causing a serious damage. It is also carcinogenic to human as determined by the International Agency for Research on cancer. (GEMS, 2007).

Copper plays an important roles in cholesterol metabolism and is also needed for the neuron transmitters while zinc helps in physiological and metal biological processes of many organs in the body.(NML, 2001). Though they may be toxic at high level of exposure. (Jorhem and Sundstroen, 1993).

However, the incidence of food related diseases is becoming rampant among the youths most especially the university students within South-West State, and there is a paucity of information on the level of Essential and Toxic Metals in food consumed by students especially in Ekiti state, of Southwest Nigeria.

Therefore the aims of this research study was to assess the level of essential metals and toxic metals exposure through staple food consumption by the students, in Ekiti state, South-West, Nigeria and the public health impact of the exposure.

\section{Materials and Methods}

\subsection{Sampling and Sampling Record}

Based on the nutritional importance of this study, standardized questionnaire designed was used as an instrument to find out kinds of staple foods commonly consumed by the students in Ekiti states southwest Nigeria. Prior to the distribution of the questionnaire, the validity of the questionnaire was determined. The questionnaire designed includes the following data information: Age, sex, weight of the respondent state of origin, location, father's occupation, mother's occupation, guidance's occupation, self occupation/self sponsor, and commonly consumed by the respondent staple food.

In addition the questionnaire also indicates how often these foods were consumed and the frequent ailment affecting the respondents. The questionnaires were distributed among the two hundred volunteered students from the representative University.

After the collection of the questionnaire from the respondents, the reliability of the instrument from the pilot study was determined to be 0.76 by using Alpa cornbach coefficient.

\subsection{Collections of Samples}

Questionnaire indicated the followings: Spaghetti, jollof rice, white rice, wheat, palp, semovita, indomie, white and red beans, beans cake (akara), moin-moin, melon, groundnut, yam, amala (Cassava and yam Flour),(fried cassava) Eba, potato and fufu as staple food items usually consumed by the students in Ekiti State. The staple foods were categorized into cereals, legumes and tubers. The identified staple foods were purchased from food vendors in the research locations.

\subsection{Sample Preservation and Pretreatment for the Solid Food Items}

Each food sample (e.g. Yam, rice and beans) was put into clean centrifuge tubes, air-dried for about $2-3$ days in a clean laboratory environment and further oven dried at $105^{\circ} \mathrm{C}$ for 24 hour and pulivensed.

\subsection{Sample Digestion and Metal Analysis}

One gramme each of the solid staple food was digested using dry ashing. The digest were analysed for zinc, copper, lead and cadmium using Atomic Absorption Spectrophotometer (AAS, Perkin Elmer Model 2130). Data were subjected to descriptive statistics. (AOAC, 2003).

\subsection{Quality Assurance and Quality Control}

Quality assurance and quality control during the course of this study were ensured by meticulously following written procedures for sampling handling both on the field and in the laboratory, and all instruments and equipments were calibrated before use. (AOAC, 1996).

\section{Result and Discussion}

Heavy metal concentrations of the food samples in $\mathrm{mg} / \mathrm{kg}$ were reported in Table 1. 
Table 1. Heavy Metal Concentration ( $\mathrm{mg} / \mathrm{kg}$ ) of Food Items in $\mathrm{mg} / \mathrm{kg}$

\begin{tabular}{|c|c|c|c|c|}
\hline \multirow[b]{2}{*}{ Food items } & \multicolumn{4}{|c|}{ Heavy Metal (mg/kg) } \\
\hline & $\mathrm{Zn}$ & $\mathrm{Cu}$ & $\mathrm{Cd}$ & $\mathrm{Pb}$ \\
\hline \multicolumn{5}{|c|}{ Cereals /Cereal product and others } \\
\hline Spaghetti & 3.63 & 2.80 & 0.16 & 0.13 \\
\hline Jollof Rice & 10.0 & 5.00 & 0.10 & LT DL \\
\hline Rice with stew & 10.9 & 4.00 & 0.47 & LT DL \\
\hline Rice with beans \& fish & 14.7 & 12.4 & 0.50 & 0.30 \\
\hline Palp with milk (Solid) & 23.0 & 3.30 & 0.40 & 0.20 \\
\hline Wheat with soup & 39.5 & 3.40 & 0.20 & 0.22 \\
\hline Semovita with soup & 18.0 & 6.90 & 0.30 & 0.03 \\
\hline Indomine & 29.4 & 5.50 & 0.25 & LT DL \\
\hline Ordinary palp & 0.43 & 2.40 & 0.20 & LT DL \\
\hline Semovita & 11.0 & 1.30 & 0.20 & 0.10 \\
\hline \multicolumn{5}{|c|}{ Legumes/Legumes product with others } \\
\hline Beans (White) & 3.48 & 1.05 & 0.01 & 0.01 \\
\hline Beans with plantain & 25.4 & 6.00 & 0.28 & 0.15 \\
\hline Akara ball & 34.9 & 4.50 & 0.07 & 0.16 \\
\hline White bean with rice \& fish & 11.0 & 4.70 & LT DL & 0.20 \\
\hline Moinmoin & 8.67 & 9.48 & 0.35 & 0.01 \\
\hline Beans with garri & 13.8 & 3.46 & LT DL & 0.25 \\
\hline Melon & 18.9 & 2.34 & 0.01 & 0.10 \\
\hline White beans, rice with palm oil & 7.22 & 4.50 & 0.05 & LT DL \\
\hline Groundnut & 14.0 & 17.6 & 0.26 & 0.05 \\
\hline Sweet Beans (Red) & 23.0 & 2.01 & & LT DL \\
\hline \multicolumn{5}{|c|}{ Tubers/Tubers product with others } \\
\hline Yam & 9.25 & 4.50 & 0.01 & 0.03 \\
\hline Pounded Yam With Melon & 18.1 & 8.13 & 0.05 & 0.05 \\
\hline Amala (Cassava Flour) & 11.3 & 3.84 & 0.03 & 0.14 \\
\hline Amala (Yam Flour) & 9.20 & 2.15 & LT DL 0.02 & 0.30 \\
\hline Eba With Melon & 6.10 & 3.45 & 0.03 & 0.30 \\
\hline Fried Cassava (Garri) & 5.21 & 1.07 & LT DL 0.02 & 0.30 \\
\hline Yam With Oil & 11.5 & 2.95 & 0.05 & 0.30 \\
\hline Yam With Egg & 16.0 & 6.43 & LT DL & 0.30 \\
\hline Potato & 13.0 & 0.82 & & 0.30 \\
\hline Fufu & 6.26 & 1.32 & & 0.15 \\
\hline
\end{tabular}

LTDL $\Rightarrow$ Less than detection limit

Detection Limits for the metals

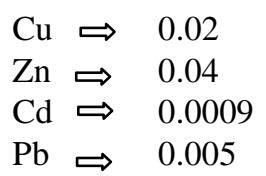

Heavy metal uptake in staple foods could be from the soil of the cultivated area, the atmospheric condition and partly from the irrigated water. In this studies heavy metal concentration were determined by atomic absorption spectroscopy in $\mathrm{mg} / \mathrm{kg}$.

The result of concentrations of the essential metals $(\mathrm{Cu}$ and $\mathrm{Zn})$ and toxic metals $(\mathrm{Pb}$ and $\mathrm{Cd})$ in the staple food samples given in Table 1 shows that the metal concentrations were within the following range: $\mathrm{Zn}(0.43-39.5)$, $\mathrm{Cu}(0.82$ - 17.6), Cd (LTDL - 0.50) and Pb (LDTL - 0.30) all in $\mathrm{mg} / \mathrm{kg}$. Highest level (mg/kg) of zinc (39.5), copper (17.6), and cadmium (0.50) were observed in wheat, beans and rice respectively. Lead determination was shown significantly high in yam, Amala (yam and cassava flour), Garri (fried cassava), and potato. 
Table 2. Average levels (mg/kg) of Zinc, Copper, Cadmium and Lead in various food groups

\begin{tabular}{|c|c|c|c|c|c|c|c|c|}
\hline \multirow[t]{2}{*}{ Food items } & \multicolumn{2}{|l|}{$\mathrm{Zn}$} & \multicolumn{2}{|l|}{$\mathrm{Cu}$} & \multicolumn{2}{|l|}{$\mathrm{Cd}$} & \multicolumn{2}{|l|}{$\mathrm{Pb}$} \\
\hline & Mean \pm S.D & Range & Mean \pm S.D & Range & Mean \pm S.D & Range & Mean \pm S.D & Range \\
\hline $\begin{array}{l}\text { Cereals Products } \\
\text { (A) }\end{array}$ & $16 . .6 \pm 11.9$ & $0.43-39.5$ & $4.70 \pm 2.99$ & $1.30-12.2$ & $20.28 \pm 0.23$ & $0.06-0.50$ & $0.10 \pm 0.15 \quad \mathrm{~L}$ & LTDL - 0.30 \\
\hline $\begin{array}{l}\text { Legumes products } \\
\text { with others (B) }\end{array}$ & $16.1 \pm 10.5$ & $3.48-34.9$ & $5.60 \pm 5.10$ & $1.05-17.6$ & $60.10 \pm 0.10 \quad \mathrm{~L}$ & LTDL-0.50 & $0.10 \pm 0.10 \quad \mathrm{~L}$ & LTDL -0.25 \\
\hline $\begin{array}{l}\text { Tubers product } \\
\text { with others (C) }\end{array}$ & $11.1 \pm 5.34$ & $6.26-18.1$ & $3.70 \pm 3.30$ & $0.82-8.13$ & $30.02 \pm 0.02 \quad \mathrm{I}$ & LTDL-0. 50 & $00.22 \pm 0.17 \quad 0$ & $0.03-0.30$ \\
\hline
\end{tabular}

The mean concentration $(\mathrm{mg} / \mathrm{kg})$ of zinc, copper, cadmium and lead ranged respectively as follows: $11.1 \pm 5.34-16.6 \pm 11.9,3.70 \pm 3.30-5.60 \pm 5.10,0.02 \pm 0.02-0.28 \pm 0.023$ and $0.10 \pm 0.10-0.22 \pm 0.17$ respectively.

Highest concentrations $(\mathrm{mg} / \mathrm{kg})$ of zinc $(16.6 \pm 11.9)$ cadmium $(0.28 \pm 0.023)$ were found in cereals while the highest concentrations of copper $(5.60 \pm 5.10)$ and lead $(0.22 \pm 0.17)$ were found in legumes and tubers respectively. The concentration of zinc, copper and lead were within the permissible limits set by FAO/WHO guidelines for food standard while cadmium concentrations in cereals such as rice and wheat were above the permissible limits. Recommended permissible limit of Zinc, copper, lead, and cadmium are $99.0 \mathrm{mg} / \mathrm{kg}, 40.0$ $\mathrm{mg} / \mathrm{kg}, 0.30 \mathrm{mg} / \mathrm{kg}$ and $0.20 \mathrm{mg} / \mathrm{kg}$ respectively as set by FAO/WHO (2001).

Percentage recovery for the metals $\mathrm{Zn}, \mathrm{Cu}, \mathrm{Cd}$ and $\mathrm{Pb}$ obtained were 92.2\%, 94.3\%, 96.0\% and 98.2\% respectively. This result shows that the error in the concentration of the toxic and essential metals found in the food samples were within the acceptable limit of $100 \pm 20 \%$.

Table 3. Comparison of $\mathrm{Cu}$ and $\mathrm{Zn}$ levels $(\mathrm{mg} / \mathrm{kg}$ ) in some Nigerian foods with levels in similar foods in other countries

\begin{tabular}{|c|c|c|c|c|c|c|c|c|c|c|c|c|c|c|}
\hline \multirow[t]{2}{*}{ Food } & \multicolumn{2}{|c|}{ This Study } & \multicolumn{2}{|c|}{ Nigeria $^{a}$} & \multicolumn{2}{|c|}{ Nigeria $^{b}$} & \multicolumn{2}{|c|}{ Sweden $^{c}$} & \multicolumn{2}{|c|}{ East Asia $^{\mathrm{d}}$} & \multicolumn{2}{|c|}{$\mathrm{USA}^{\mathrm{e}}$} & \multicolumn{2}{|c|}{$\mathrm{USA}^{\mathrm{f}}$} \\
\hline & $\mathrm{Cu}$ & $\mathrm{Zn}$ & $\mathrm{Cu}$ & $\mathrm{Zn}$ & $\mathrm{Cu}$ & $\mathrm{Zn}$ & $\mathrm{Cu}$ & $\mathrm{Zn}$ & $\mathrm{Cu}$ & $\mathrm{Zn}$ & $\mathrm{Cu}$ & $\mathrm{Zn}$ & $\mathrm{Cu}$ & $\mathrm{Zn}$ \\
\hline Beef & 1.20 & 7.00 & 0.89 & 48.0 & - & - & 1.60 & 23.5 & 1.60 & 22.0 & 7.24 & 81.7 & 0.58 & 10.5 \\
\hline Beans & 2.01 & 23.0 & 6.87 & 42.7 & 1.30 & 0.75 & 5.60 & 27.0 & 8.80 & 11.0 & 2.72 & 14.0 & 3.08 & 29.1 \\
\hline Sugar & 0.10 & 1.80 & 0.33 & 0.60 & - & - & 0.23 & 0.06 & - & - & 0.09 & 0.10 & 0.29 & 2.85 \\
\hline Potato & 0.82 & 13.0 & 0.72 & 3.00 & - & - & 0.72 & 3.00 & 2.30 & 0.30 & 0.64 & 2.10 & 0.60 & 7.66 \\
\hline Pork & - & - & 2.87 & 30.2 & - & - & 0.90 & 34.0 & 1.90 & 25.0 & 0.95 & 30.8 & 0.80 & - \\
\hline Corn & 3.35 & 20.4 & 2.33 & 33.4 & 1.30 & 8.00 & - & & 1.60 & 14.0 & 0.48 & 6.10 & 0.38 & 4.39 \\
\hline Yam & 4.50 & 9.25 & 4.73 & 10.0 & 2.20 & 2.70 & - & & - & 11.0 & - & - & - & - \\
\hline Rice & 4.00 & 10.9 & 1.53 & 4.93 & 1.40 & 3.00 & - & & 2.30 & 15.0 & 0.73 & 5.70 & 1.90 & 9.35 \\
\hline Bread & 0.88 & 1.08 & 0.60 & 2.93 & - & - & - & & - & - & 1.11 & 7.20 & 1.32 & 8.20 \\
\hline Egg & - & - & 1.13 & 6.87 & - & - & - & & 0.50 & 9.0 & 0.64 & 14.6 & 0.80 & 12.3 \\
\hline
\end{tabular}

Table 3 shows comparison of $\mathrm{Cu}$ and $\mathrm{Zn}$ levels $\mathrm{mg} / \mathrm{kg}$ in some Nigerian foods with levels in similar foods in other country.

Zinc concentration for rice $(10.9 \mathrm{mg} / \mathrm{kg})$ in this study is close to the value $(9.35 \mathrm{mg} / \mathrm{kg})$ obtained by Hussean and Bruggeman (1997) in U.S.A. The Zinc concentration $(9.25 \mathrm{mg} / \mathrm{kg})$ for yam in this study is very to the value (10.0 $\mathrm{mg} / \mathrm{kg}$ ) obtained by Onianwa et al. (2001) in Nigeria. Also Copper level $(4.50 \mathrm{mg} / \mathrm{kg}$ ) in yam in this study is very close to the copper level obtained for yam $(4.73 \mathrm{mg} / \mathrm{kg})$ in Nigeria by Onianwa et al. (2001). Copper level (0.82 $\mathrm{mg} / \mathrm{kg}$ ) in potato (tuber product) in this study is very close to the copper level $(0.72 \mathrm{mg} / \mathrm{kg}$ ) obtained for potato by Onianwa et al. (2001) in Nigeria. 
Zinc level $(23.0 \mathrm{mg} / \mathrm{kg})$ in beans (legume products) in this study compares well with zinc level $(27.0 \mathrm{mg} / \mathrm{kg})$ in beans obtained in Sweden by Jorhem and Sundstroen (1993).

\section{Conclusion and Recommendation}

Conclusion: Zinc, copper, cadmium and lead were identified as contaminant in staple foods that are commonly consumed by university students in Ekiti State in this current study. Most items consumed by the students were relatively safe in terms of essential and toxic metal contamination, except for cereal products the most frequently consumed staple food by the students in the research area as indicated in the questionnaires which are contaminated, because the cadmium level exceeded the safe limit.

\section{Recommendation}

Based on the findings of this study we could see that highly toxic metals like cadmium etc. were found in some of the staple food items consumed by the students in Ekiti State which could have long term effect on human health. To safeguard this undesirable effect the followings are recommended

1. The attention of the Local, State, and Federal Ministry of Health in Nigeria should be drawn to presence of toxic metals in different kinds processed and unprocessed staple food items base on the evidences provided by this study

2. The result of this research should also serve as a point of reference for enacting regulators and laws that control inputs of toxic metals in food during plantation and processing periods

3. Public awareness especially to the students on the potential danger of frequent consumption of metal contaminated food should be created.

\section{References}

Agency for Toxic Substances and Disease Registry. (2011). Information for the community lead toxicity. Accessed from http://www.atsdr.cdc.gov/csem/lead/community/index.html.

AOAC. (1996). Cadmium, copper, and Iron, magnesium, manganese, phosphorus, potassium, sodium and zinc in infant formula. Inductively coupled plasma. Emission Spectrosccfc opic Method, first action 1984, final action 1986. AOAC International.

AOAC. (2003). Official Method 999.10. Lead, cadmium, zinc, copper and Iron in foods, atomic absorption spectrophotometry after microwave digestion. AOAC Official Method 984:27.

FAO/WHO. (2001). Codex Alimentarius. Geneva, World Health Organization.

Hussein, L., \& Bruggeman, J. (1997). Selected Mineral Intakes of Adult African-Americans in the Washington. Journal of Food Composition and Analysis, 10, 334-342.

Jorhem, L., \& Sundstroen. (1993). Determination of metals in foodstuffs by atomic absorption spectrophotometry after dry ashing: NMKL interlaboratory study of lead, cadmium, zinc, copper, iron, chromium and nickel. Journal of AOAC International, 76, 798-13.

NML. (2001). Treatment of Metal Toxicity. Journal of National Medical Library 130.

Onianwa, P. C, Adeyemo, A. O, Idowu, O. E., \& Ogabiela, E. E. (2001). Copper and zinc contents of Nigerian foods and estimates of the adult dietary intakes. Food chemistry, 72, 89-95.

World Health Organization. (2007). Micronutrient deficiencies. Battling iron deficiency anemia Nutrition Program. http://www.who.int/nut/ida.htm. 


\section{APPENDIX}

\section{QUESTIONNAIRE ON}

\section{TOXIC AND ESSENTIAL METALS IN STAPLE FOOD ITEMS AND DRINKS COMMONLY CONSUMED BY STUDENTS IN EKITI STATE OF SOUTHWEST NIGERIA}

This questionnaire is designed to find out kinds of staple foods that are commonly consumed by students in Ekiti state of Southwest Nigeria.

I shall be grateful if the correct information required is given.

(1) Age:

(2) Sex:

(3) Weight:

(4) State of Origin:

(5) City /Community:

(6) Father's Occupation:

(7) Mother's occupation:

(8) Common Staple food intake

(9) How often do you eat the staple food? Often

(10) Do you have a particular ailment that usually disturbs you? Yes

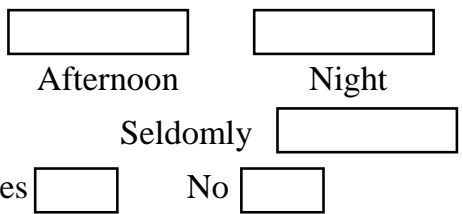

(11) If yes, indicate $\square$ e.g. (headache, stomach ache, constipation fatigue and diarrhea

(12) If yes how often? Very often $\square$ often $\square$ seldomly $\square$

\section{Copyrights}

Copyright for this article is retained by the author(s), with first publication rights granted to the journal.

This is an open-access article distributed under the terms and conditions of the Creative Commons Attribution license (http://creativecommons.org/licenses/by/3.0/). 